\title{
MICROBIOLOGICAL EVALUATION OF SOME DRIED DAIRY DRINKS SOLD IN ASSIUT CITY
}

\author{
MARWA M.N. EL-GENDI and ZEINAB M. ABDEL-HAMEED \\ Animal Health Research Institute (Assiut Provincial Lab.) Food Hygiene Department
}

Received: 28 July 2016; Accepted: 4 August 2016

\begin{abstract}
This study was aimed to evaluate some dried dairy drinks as salep, hot chocolate and coffee milk powder. A total of 75 random samples ( 25 each) were purchased from different dairy shops and supermarkets in Assiut city, Egypt. Each sample was microbiologically examined in both forms; powdered form (as it was packed) and reconstituted form (as manufacturing instructions) as well as isolation of Bacillus cereus and detection of its toxigenic genes (cytK, and $h b l C$ ) using PCR technique was performed. The obtained results showed that the average psychrotrophic counts in the powdered form were $1.2 \times 10^{3}, 3.6 \times 10^{2}$ and $80 \mathrm{cfu} / \mathrm{g}$, respectively; and the counts in the reconstituted form were $1.25 \times 10^{4}, 1.69 \times 10^{4}$ and $7.8 \times 10^{3} \mathrm{cfu} / \mathrm{g}$, respectively. Moreover, the average thermophilic counts in the powdered form were $2.68 \times 10^{3}, 40$ and $40 \mathrm{cfu} / \mathrm{g}$, respectively; and in the reconstituted form were $6.8 \times 10^{2}, 40$ and $<10 \mathrm{cfu} / \mathrm{g}$, respectively. The average counts of total yeasts and molds in the powdered form of the examined samples were $1.72 \times 10^{3}, 1.6 \times 10^{2}$ and $1.01 \times 10^{3} \mathrm{cfu} / \mathrm{g}$, respectively, and the counts in the reconstituted form were $9.6 \times 10^{2}, 9.2 \times 10^{2}$ and $2.6 \times 10^{3} \mathrm{cfu} / \mathrm{g}$, respectively. Regarding the total Bacillus count, the average counts in the powdered form were $4 \times 10^{2}, 3.2 \times 10^{2}$ and $40 \mathrm{cfu} / \mathrm{g}$, respectively; $1.8 \times 10^{3}, 1.96 \times 10^{3}$ and $2 \times 10^{2} \mathrm{cfu} / \mathrm{g}$ were the counts in the reconstituted form, respectively. In addition, identification of the isolated Bacillus species was performed and recorded in the previous products. By using PCR, twenty eight strains of the isolated B. cereus were enterotoxigenic.
\end{abstract}

Key words: Salep, Hot chocolate, Coffee milk powder, Enterotoxigenic B. cereus

\section{INTRODUCTION}

Nowadays, there are many dried dairy drinks that consumed as hot drinks in Egypt as salep, hot chocolate and coffee milk powder. The product salep is pronounced in Arabic dialect as Sahlab.

In the recent years, hot chocolate and coffee milk powder are generally prepared for immediate consumption and not stored in sealed bottles or cans. These drinks are consumed at home or through takeaway beverage shops, however, these drinks may have variable microbiological quality. Unhygienic handling of these ingredients may result in contamination and improper storage which allow microorganisms to multiply to a high level. Hotserved drinks are generally prepared with boiling hot water where microbiological hazards could be reduced by the high temperature; also, these drinks are more likely to be prepared upon ordering.

Salep was a popular beverage in the lands of the Ottoman Empire. Its consumption spread beyond

Corresponding author: Dr. ZEINAB M. ABDEL-HAMEED E-mail address: Zenb@dr.com; moazahmednofel@yahoo.com Present address: Animal Health Research Institute (Assiut Provincial Lab.) Food Hygiene Department there to England and Germany before the rise of coffee and tea and it was later offered as an alternative beverage in coffee houses. In England, the drink was known as saloop, popular in the $17^{\text {th }}$ and $18^{\text {th }}$ centuries, its preparation required that the salep powder be added to water until thickened whereupon it would be sweetened, then flavored with orange flower or rose water. Substitution of British orchid roots, known as "dogstones", was acceptable in the $18^{\text {th }}$ century for the original Turkish variants (Davidson, 1987).

Hot chocolate, also known as hot cocoa, is a heated beverage consisting of shaved chocolate, melted chocolate or cocoa powder, heated milk or water, and often sugarand considered a comfort food and is widely consumed in many parts of the world like USA (Sciscenti, 2015). Research has shown that the consumption of hot chocolate can be positive to one's health. A study conducted by Cornell University has shown that hot chocolate contains more antioxidants than wine and tea, therefore reducing the risk of heart disease (American ChemicalSociety, 2003).

Food safety control aims to safeguard public health and provide assurance on food safety. Microbiological analyses are useful ways to assess the safety and quality of food involved. Instant drinks 
are convenience products that require very little effort to reconstitute prior to consumption. Salep, ground cocoa based beverages (hot chocolate) and coffees milk powder are classified as instant foods that contain milk powder simply mixed with sugar or not. They are sources of high calorie intake and mineral nutrition (Shittu and Lawal, 2007).

Psychrotrophic bacteria are becoming increasingly dangerous to the dairy industry because they produce extracellular heat - resistant lipases and proteases (Sorhaug and Stepaniak, 1997). Moreover, the thermophilic bacilli could not only cause spoilage due to their production of acids and the rmostable enzyme excretion, but also cause food borne illness (Burgess et al., 2010).

Yeasts themselves are not commonly the cause of defect in dairy products unless they ferment lactose. In this case, they can grow rapidly and produce a characteristic yeasty or fruity flavor and obvious gas.. The presence of wild types of molds is undesirable as they may influence the organoleptic characteristics of the dairy products, they can produce mycotoxins and represent a potential health risk (Wouters et al., 2002). Spoilage of dairy products by molds is frequent and a matter of concern for human health.

Bacillus cereus is a common contaminant frequently isolated from foods and dairy products and the fact that the bacterium has a remarkable ability to survive different environmental stresses makes it difficult to be removed from dairy products. The spores survive pasteurization and transfer from milk to pasteurized milk products. The psychrotrophic strains often limit the keeping quality of pasteurized milk and its products (Giffel et al., 1996). Cases of B. cereus food poisoning in milk-based products have been reported (Meer et al., 1991; Andersson et al., 1995; Schoeni and Wang, 2005) and as many as 69-85\% psychrotrophic B. cereus isolates from milk and milk products have been found to be enterotoxigenic (Griffiths, 1990). B. cereus produces two types of toxins - emetic (vomiting) and diarrhoeal - causing two types of illness. The emetic syndrome is caused by emetic toxin produced by the bacteria during the growth phase in the food. The diarrhoeal syndrome is caused by diarrhoeal toxins produced during growth of the bacteria in the small intestine (Ehling-Schulz et al., 2006). B. cereus is responsible for several outbreaks of foodborne diseases due to its emetic toxin and enterotoxin. Enterotoxins, cytotoxin $\mathrm{K}$ (CytK), nonhemolytic enterotoxin (Nhe) and hemolysin BL ( $\mathrm{Hbl})$, have been recorded in several diarrheal cases due to food poisoning from B. cereus (Zhang et al., 2016).

One of the objectives of this study was to use multiplex PCR to detect enterotoxin-producing $B$. cereus in some dried dairy drinks. The specificity of primers of two enterotoxins; $c y t K$ and $h b l C$ of $B$. cereus was verified by inclusivity and exclusivity tests using single PCR.

The aim of the present study was to investigate the microbiological quality of some dried dairy drinks that consumed hot with special focus on the incidence of enterotoxigenic $B$. cereus in the examined products.

\section{MATERIAL AND METHODS}

\begin{abstract}
A) Sampling:
A total of 75 random samples of salep, hot chocolate and coffee milk powder (25 each) were purchased from different dairy shops and supermarkets in Assiut city, Egypt; in the period from May to June 2015. All the samples were still valid for consumption. Cartons and packets of the samples were cleaned, thoroughly mixed and aseptically opened. Tenfold serial dilution was carried out according to A.P.H.A. (1992). Microbiological examination was done for the samples before preparation (powdered form) and after preparation (reconstituted form). Preparation of the samples was proceed according to the manufacturing methods by using sterile distilled water.
\end{abstract}

B) Total psychrotrophic count: was done according to Gilliland et al. (1976).

C) Enumeration of total thermophiles:

One $\mathrm{ml}$ of the sample and its decimal dilutions was plated using milk plate count agar (MPCA) and incubated at $55^{\circ} \mathrm{C}$ for $48 \mathrm{~h}$ as described by Frank and Yousef (2004).

D) Enumeration of total yeasts and molds: was done according to Harrigan and MacCance (1976) by using malt extract agar (containing $500 \mathrm{mg}$ each of chlortetracycline and HCL chloramphenicol).

\section{E) Total Bacillus spp. count:}

One milliliter from each dilution was mixed with molten $\left(45^{\circ} \mathrm{C}\right)$ mannitol-egg yolk-polymyxin (MYP) agar (FDA, 1998) and incubated at $37^{\circ} \mathrm{C}$ for 24 to 48 h. The colonies that appeared were counted and identified.

F) Isolation of $\boldsymbol{B}$. cereus: was done according to Varadaraj (1993)

B. cereus was isolated using surface plating technique on polymyxin-pyruvate-eggyolk-mannitolbromothymol blue agar (PEMBA) (Oxoid). B. cereus was appeared as peacock blue coloured colonies surrounded by a zone of precipitation of egg yolk. The isolates of typical colonies were picked for further identification.

G) Identification of $B$. cereus isolates:

The isolated organisms were identified microscopically and biochemically according to Koneman et al. (1992): 


\section{Microscopical identification:}

1.1. Staining

1.2. Motility test

2. Biochemical identification:

2.1. Catalase test

2.2. Egg yolk lecithinase

2.3. Nitrate reduction test

2.4. Modified VogusProskauer test

2.5. Citrate utilization test

2.6. Gelatin hydrolysis

2.7. Starch hydrolysis

2.8. Indole production test

2.9. Sugar fermentation
3. Serological identification: was done according to TeGiffel et al. (2000)

H) Polymerase Chain Reaction (PCR) technique:

1.1. Material used for PCR for detection of $B$. cereus enterotoxins genes:

Protocol applied for DNA Extraction using QIA amp kit was done according to Shah et al. (2009).

1.2. Primer sequences of $B$. cereus used for PCR identification system: Application of PCR for identification of heamolysin BL ( $h b l C)$ and cytotoxic $\mathrm{K}(c y t K)$ genes of $B$. cereus was performed essentially by using Primers (Pharmacia Biotech) as shown in the following table:

\begin{tabular}{|c|c|c|c|c|}
\hline Target gene & Primer & Oligonucleotide sequence $\left(5^{\prime} \rightarrow 3^{\prime}\right)$ & Product size (bp) & Reference \\
\hline \multirow{2}{*}{ hblC } & $F H b l C(\mathrm{~F})$ & 5' CCTATCAATACTCTCGCAA '3 & \multirow{2}{*}{695} & \multirow{2}{*}{$\begin{array}{l}\text { Ngamwongsatit } \\
\text { et al. (2008) }\end{array}$} \\
\hline & $R H b l C(\mathrm{R})$ & $\mathbf{5}^{\prime}$ TTTCCTTTGTTATACGCTGC ' $\mathbf{3}$ & & \\
\hline \multirow{2}{*}{ cytK } & FCytK (F) & 5' CGACGTCACAAGTTGTAACA ' $\mathbf{3}$ & \multirow{2}{*}{565} & \multirow{2}{*}{$\begin{array}{l}\text { Ngamwongsatit } \\
\text { et al. (2008) }\end{array}$} \\
\hline & RCytK (R) & 5' CGTGTGTAAATACCCCAGTT ' $\mathbf{3}$ & & \\
\hline
\end{tabular}

1.3. Amplification reaction of $B$. cereus (Ngamwongsatit et al., 2008):

The amplification was performed on a Thermal Cycler (Master cycler, Eppendorf, Hamburg, Germany). The multiplex PCR amplification was performed in a final volume of $20 \mathrm{ul}$ containing $5 \mu \mathrm{l}$ of DNA templates with final concentration $1 \mathrm{X}$ PCR buffer $(10 \mathrm{mM}$ Tris- $\mathrm{HCl} \mathrm{pH} 8.3$ and $50 \mathrm{mMKCl})$, $1.5 \mathrm{mM} \mathrm{MgCl} 2,200 \mu \mathrm{M}$ of each dNTP, 5U Taq DNA polymerase and $0.4 \mu \mathrm{MhlbC}$ primer and $0.2 \mu \mathrm{McytK}$ primer. Reactions were carried out with the following cycling conditions: initial denaturation at $95^{\circ} \mathrm{C}$ for 5 min, followed by 30 cycles of $94^{\circ} \mathrm{C}$ for $45 \mathrm{sec}$, annealing at $54^{\circ} \mathrm{C}$ and $56^{\circ} \mathrm{C}$ for $1 \mathrm{~min}$ in case of hblC and at $58^{\circ} \mathrm{C}$ in case of cytK, elongation at $72^{\circ} \mathrm{C}$ for 2 min and final extension at $72^{\circ} \mathrm{C}$ for $5 \mathrm{~min}$. Amplified products were analyzed by $1.5 \%$ of agarose gel electrophoresis (Applichem, Germany, GmbH) in 1x TBE buffer stained with ethidium bromide and captured as well as visualized on UV transilluminator. A 100 bp plus DNA Ladder (Qiagen, Germany, GmbH) was used to determine the fragment sizes.

\section{RESULTS}

Table 1: Statistical analytical result of total psychrotrophic count of the examined samples ( $n=25$ of each).

\begin{tabular}{|c|c|c|c|c|c|c|c|c|c|c|c|c|c|}
\hline \multirow{3}{*}{\multicolumn{2}{|c|}{$\begin{array}{l}\text { Positive no. of } \\
\text { the examined } \\
\text { samples }\end{array}$}} & \multicolumn{4}{|c|}{ Salep } & \multicolumn{4}{|c|}{ Hot chocolate } & \multicolumn{4}{|c|}{ Coffee milk powder } \\
\hline & & \multicolumn{2}{|c|}{ powdered } & \multicolumn{2}{|c|}{ reconstituted } & \multicolumn{2}{|c|}{ powdered } & \multicolumn{2}{|c|}{ reconstituted } & \multicolumn{2}{|c|}{ powdered } & \multicolumn{2}{|c|}{ reconstituted } \\
\hline & & No. & $\%$ & No. & $\%$ & No. & $\%$ & No. & $\%$ & No. & $\%$ & No. & $\%$ \\
\hline & & 8 & 32 & 13 & 52 & 1 & 4 & 9 & 36 & 1 & 4 & 2 & 8 \\
\hline \multirow{3}{*}{ 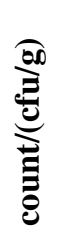 } & Max. & \multicolumn{2}{|c|}{$7 \times 10^{3}$} & \multicolumn{2}{|c|}{$5.8 \times 10^{4}$} & \multicolumn{2}{|c|}{$9 \times 10^{3}$} & \multicolumn{2}{|c|}{$1.4 \times 10^{5}$} & \multicolumn{2}{|c|}{$2 \times 10^{3}$} & \multicolumn{2}{|c|}{$1.3 \times 10^{5}$} \\
\hline & Min. & \multicolumn{2}{|c|}{$*<10$} & \multicolumn{2}{|c|}{$*<10$} & \multicolumn{2}{|c|}{$*<10$} & \multicolumn{2}{|c|}{$*<10$} & \multicolumn{2}{|c|}{$*<10$} & \multicolumn{2}{|c|}{$*<10$} \\
\hline & Average & \multicolumn{2}{|c|}{$1.2 \times 10^{3}$} & \multicolumn{2}{|c|}{$1.25 \times 10^{4}$} & \multicolumn{2}{|c|}{$3.6 \times 10^{2}$} & \multicolumn{2}{|c|}{$1.69 \times 10^{4}$} & \multicolumn{2}{|c|}{80} & \multicolumn{2}{|c|}{$7.8 \times 10^{3}$} \\
\hline
\end{tabular}

$*<10$ means no colonies were detected in the plates. 
Table 2: Statistical analytical results of total the rmophilic count of the examined samples ( $\mathrm{n}=25 \mathrm{of}$ each).

\begin{tabular}{|c|c|c|c|c|c|c|c|c|c|c|c|c|c|}
\hline \multirow{4}{*}{\multicolumn{2}{|c|}{$\begin{array}{l}\text { Positive no. of } \\
\text { the examined } \\
\text { samples }\end{array}$}} & \multicolumn{4}{|c|}{ Salep } & \multicolumn{4}{|c|}{ Hot chocolate } & \multicolumn{4}{|c|}{ Coffee milk powder } \\
\hline & & \multicolumn{2}{|c|}{ powdered } & \multicolumn{2}{|c|}{ reconstituted } & \multicolumn{2}{|c|}{ powdered } & \multicolumn{2}{|c|}{ reconstituted } & \multicolumn{2}{|c|}{ powdered } & \multicolumn{2}{|c|}{ reconstituted } \\
\hline & & No. & $\%$ & No. & $\%$ & No. & $\%$ & No. & $\%$ & No. & $\%$ & No. & $\%$ \\
\hline & & 11 & 44 & 4 & 16 & 1 & 4 & 1 & 4 & 1 & 4 & $\mathbf{0}$ & $\mathbf{0}$ \\
\hline \multirow{3}{*}{$\underbrace{\stackrel{000}{E}}_{\stackrel{0}{0}}$} & Max. & \multicolumn{2}{|c|}{$2.6 \times 10^{4}$} & \multicolumn{2}{|c|}{$6 \times 10^{3}$} & \multicolumn{2}{|c|}{$1 \times 10^{3}$} & \multicolumn{2}{|c|}{$1 \times 10^{3}$} & \multicolumn{2}{|c|}{$1 \times 10^{3}$} & \multicolumn{2}{|c|}{${ }^{*}<10$} \\
\hline & Min. & \multicolumn{2}{|c|}{$*<10$} & \multicolumn{2}{|c|}{$*<\mathbf{1 0}$} & \multicolumn{2}{|c|}{$*<\mathbf{1 0}$} & \multicolumn{2}{|c|}{$*<\mathbf{1 0}$} & \multicolumn{2}{|c|}{$*<10$} & \multicolumn{2}{|c|}{$*<10$} \\
\hline & Average & \multicolumn{2}{|c|}{$2.68 \times 10^{3}$} & \multicolumn{2}{|c|}{$6.8 \times 10^{2}$} & \multicolumn{2}{|c|}{40} & \multicolumn{2}{|c|}{40} & \multicolumn{2}{|c|}{40} & \multicolumn{2}{|c|}{$*<10$} \\
\hline
\end{tabular}

$*<10$ means no colonies were detected in the plates.

Table 3: Statistical analytical results of total yeasts and molds count of the examined samples ( $\mathrm{n}=25 \mathrm{of}$ each).

\begin{tabular}{|c|c|c|c|c|c|c|c|c|c|c|c|c|c|}
\hline \multirow{3}{*}{\multicolumn{2}{|c|}{$\begin{array}{l}\text { Positive no. of } \\
\text { the examined } \\
\text { samples }\end{array}$}} & \multicolumn{4}{|c|}{ Salep } & \multicolumn{4}{|c|}{ Hot chocolate } & \multicolumn{4}{|c|}{ Coffee milk powder } \\
\hline & & \multicolumn{2}{|c|}{ powdered } & \multicolumn{2}{|c|}{ reconstituted } & \multicolumn{2}{|c|}{ Powdered } & \multicolumn{2}{|c|}{ reconstituted } & \multicolumn{2}{|c|}{ powdered } & \multicolumn{2}{|c|}{ reconstituted } \\
\hline & & No. & $\%$ & No. & $\%$ & No. & $\%$ & No. & $\%$ & No. & $\%$ & No. & $\%$ \\
\hline & & 7 & 28 & 6 & 24 & 3 & 12 & 8 & 32 & 8 & 32 & 7 & 28 \\
\hline \multirow{3}{*}{ 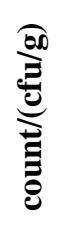 } & Max. & \multicolumn{2}{|c|}{$1 \times 10^{4}$} & \multicolumn{2}{|c|}{$7 \times 10^{3}$} & \multicolumn{2}{|c|}{$2 \times 10^{3}$} & \multicolumn{2}{|c|}{$1 \times 10^{4}$} & \multicolumn{2}{|c|}{$1.1 \times 10^{4}$} & \multicolumn{2}{|c|}{$2.1 \times 10^{4}$} \\
\hline & Min. & \multicolumn{2}{|c|}{$*<10$} & \multicolumn{2}{|c|}{$*<10$} & \multicolumn{2}{|c|}{$*<10$} & \multicolumn{2}{|c|}{$*<10$} & \multicolumn{2}{|c|}{$*<10$} & \multicolumn{2}{|c|}{$*<10$} \\
\hline & Average & \multicolumn{2}{|c|}{$1.72 \times 10^{3}$} & \multicolumn{2}{|c|}{$9.6 \times 10^{2}$} & \multicolumn{2}{|c|}{$1.6 \times 10^{2}$} & \multicolumn{2}{|c|}{$9.2 \times 10^{2}$} & \multicolumn{2}{|c|}{$1.01 \times 10^{3}$} & \multicolumn{2}{|c|}{$2.6 \times 10^{3}$} \\
\hline
\end{tabular}

$*<10$ means no colonies were detected in the plates.

Table 4: Statistical analytical results of total Bacillus count of the examined samples: ( $n=25$ of each).

\begin{tabular}{|c|c|c|c|c|c|c|c|c|c|c|c|c|c|}
\hline \multirow{3}{*}{\multicolumn{2}{|c|}{$\begin{array}{c}\text { Positive no. of } \\
\text { the examined } \\
\text { samples }\end{array}$}} & \multicolumn{4}{|c|}{ Salep } & \multicolumn{4}{|c|}{ Hot chocolate } & \multicolumn{4}{|c|}{ Coffee milk powder } \\
\hline & & \multicolumn{2}{|c|}{ powdered } & \multicolumn{2}{|c|}{ reconstituted } & \multicolumn{2}{|c|}{ Powdered } & \multicolumn{2}{|c|}{ reconstituted } & \multicolumn{2}{|c|}{ powdered } & \multicolumn{2}{|c|}{ reconstituted } \\
\hline & & No. & $\%$ & No. & $\%$ & No. & $\%$ & No. & $\%$ & No. & $\%$ & No. & $\%$ \\
\hline & & 5 & 20 & 7 & 28 & 7 & 28 & 10 & 40 & 1 & 4 & 2 & 8 \\
\hline \multirow{3}{*}{ 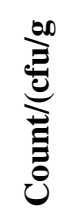 } & Max. & \multicolumn{2}{|c|}{$5 \times 10^{3}$} & \multicolumn{2}{|c|}{$1.8 \times 10^{4}$} & \multicolumn{2}{|c|}{$2 \times 10^{3}$} & \multicolumn{2}{|c|}{$1.8 \times 10^{4}$} & \multicolumn{2}{|c|}{$1 \times 10^{3}$} & \multicolumn{2}{|c|}{$4 \times 10^{3}$} \\
\hline & Min. & \multicolumn{2}{|c|}{$*<\mathbf{1 0}$} & \multicolumn{2}{|c|}{$*<10$} & \multicolumn{2}{|c|}{$*<10$} & \multicolumn{2}{|c|}{$*<10$} & \multicolumn{2}{|c|}{$*<10$} & \multicolumn{2}{|c|}{$*<10$} \\
\hline & Average & \multicolumn{2}{|c|}{$4 \times 10^{2}$} & \multicolumn{2}{|c|}{$1.8 \times 10^{3}$} & \multicolumn{2}{|c|}{$3.2 \times 10^{2}$} & \multicolumn{2}{|c|}{$1.96 \times 10^{3}$} & \multicolumn{2}{|c|}{40} & \multicolumn{2}{|c|}{$2 \times 10^{2}$} \\
\hline
\end{tabular}

*< 10 means no colonies were detected in the plates. 
Table 5: Incidence of Bacillus spp. isolated from the examined samples: $(n=25)$.

\begin{tabular}{|c|c|c|c|c|c|c|c|c|c|c|c|c|}
\hline \multirow{3}{*}{ Bacillus spp. } & \multicolumn{4}{|c|}{ Salep } & \multicolumn{4}{|c|}{ Hot chocolate } & \multicolumn{4}{|c|}{ Coffee milk powder } \\
\hline & \multicolumn{2}{|c|}{ powdered } & \multicolumn{2}{|c|}{ reconstituted } & \multicolumn{2}{|c|}{ powdered } & \multicolumn{2}{|c|}{ reconstituted } & \multicolumn{2}{|c|}{ powdered } & \multicolumn{2}{|c|}{ reconstituted } \\
\hline & No. & $\%$ & No. & $\%$ & No. & $\%$ & No. & $\%$ & No. & $\%$ & No. & $\%$ \\
\hline B. megaterium & 2 & 8 & $\mathbf{0}$ & $\mathbf{0}$ & 2 & 8 & 2 & 8 & $\mathbf{0}$ & $\mathbf{0}$ & 1 & 4 \\
\hline B. subtilis & 2 & 8 & 1 & 4 & $\mathbf{0}$ & $\mathbf{0}$ & 3 & 12 & $\mathbf{0}$ & $\mathbf{0}$ & 1 & 4 \\
\hline B. circulans & 1 & 4 & $\mathbf{0}$ & $\mathbf{0}$ & 1 & 4 & 1 & 4 & $\mathbf{0}$ & $\mathbf{0}$ & $\mathbf{0}$ & $\mathbf{0}$ \\
\hline B.licheniformis & 2 & 8 & 1 & 4 & 1 & 4 & $\mathbf{0}$ & $\mathbf{0}$ & 1 & 4 & 1 & 4 \\
\hline B.macerans & 1 & 4 & $\mathbf{0}$ & $\mathbf{0}$ & 1 & 4 & $\mathbf{0}$ & $\mathbf{0}$ & $\mathbf{0}$ & $\mathbf{0}$ & $\mathbf{0}$ & $\mathbf{0}$ \\
\hline B. sphaericus & $\mathbf{0}$ & $\mathbf{0}$ & 1 & 4 & $\mathbf{0}$ & 0 & $\mathbf{0}$ & $\mathbf{0}$ & 1 & 4 & 1 & 4 \\
\hline B. coagglans & $\mathbf{0}$ & $\mathbf{0}$ & 2 & 8 & $\mathbf{0}$ & $\mathbf{0}$ & 1 & 4 & 1 & 4 & $\mathbf{0}$ & $\mathbf{0}$ \\
\hline B. stearothermophilus & $\mathbf{0}$ & $\mathbf{0}$ & 1 & 4 & $\mathbf{1}$ & 4 & 1 & 4 & $\mathbf{0}$ & $\mathbf{0}$ & 1 & 4 \\
\hline B. polymyxa & $\mathbf{0}$ & $\mathbf{0}$ & 1 & 4 & $\mathbf{0}$ & $\mathbf{0}$ & $\mathbf{0}$ & $\mathbf{0}$ & $\mathbf{0}$ & $\mathbf{0}$ & 1 & 4 \\
\hline B. cereus & 6 & 24 & 9 & 36 & 4 & 16 & 4 & 16 & 2 & 8 & 3 & 12 \\
\hline
\end{tabular}

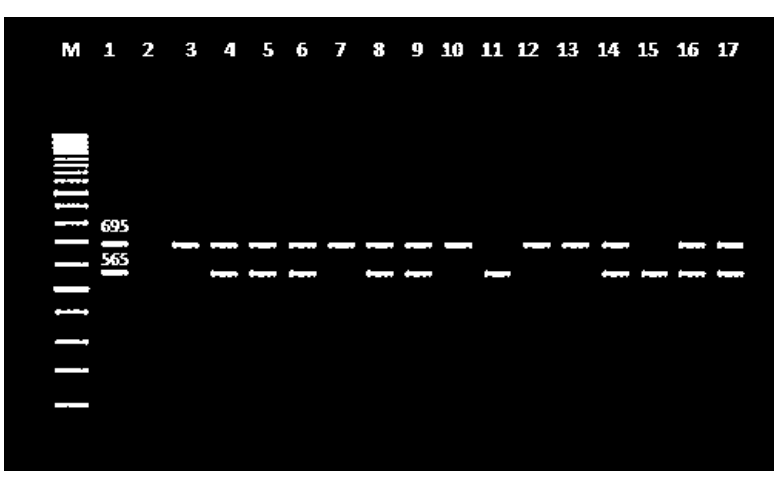

Figure 1a: Agarose gel electrophoresis of multiplex PCR of hblC (695bp) and cytK (565 bp) virulent genes for characterization of $B$. cereus.

Lane M: 100 bp ladder as molecular size DNA marker.

Lane 1: Control positive B. cereus for hblC and cytK genes.

Lane 2: Control negative.

Lanes 3, 7, 10, 12 \& 13: Positive B. cereus strains for hblC gene.

Lanes 11 \& 15: Positive $B$. cereus strains for cytK gene.

Lanes 4, 5, 6, 8, 9, 14, 16 \& 17: Positive B. cereus strains for both hblC and cytK genes.

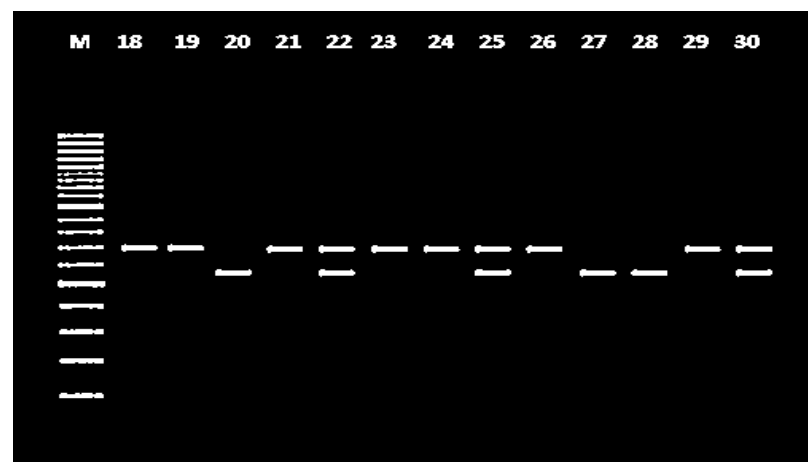

Figure 2 b: Agarose gel electrophoresis of multiplex PCR of hblC (695bp) and cytK (565 bp) virulent genes for characterization of $B$. cereus.

Lane M: $100 \mathrm{bp}$ ladder as molecular size DNA marker.

Lanes 18, 19, 21, 23, 24, 26 \& 29: Positive B. cereus strains for hblC gene.

Lanes 20, 27 \& 28: Positive B. cereus strains for cytK gene.

Lanes 22, 25 \& 30: Positive B. cereus strains for both hblC and cytK genes. 


\section{DISCUSSION}

The microbiological results of total psychrotrophic count of the tested dried dairy drinks are presented in Table 1.Out of 25 samples of salep, 8 samples in a percentage of $32 \%$ were positive for counting of total psychrotrophes in the powdered form. The maximum, minimum and average counts were $7 \times 10^{3},<10$ and $1.2 \times 10^{3} \mathrm{cfu} / \mathrm{g}$, respectively. While, $5.8 \times 10^{4},<10$ and $1.25 \times 10^{4}$ were the maximum, minimum and average counts of the salep samples as the reconstituted form, respectively. The number of positive samples increased after reconstitution of the salep samples to become 13 samples in a percentage of $52 \%$. $9 \times 10^{3}$ and $1.4 \times 10^{5}$ were the maximum counts of the hot chocolate examined samples of the powdered and reconstituted forms, respectively in percentages of 4 and $36 \%$ as shown in Table 1.4 and $8 \%$ of the examined samples of coffee milk powder were positive for total psychrotrophic count in the powdered and reconstituted forms, respectively with maximum numbers of $2 \times 10^{3}$ and $1.3 \times 10^{5} \mathrm{cfu} / \mathrm{g}$

The total the rmophilic counts ranged from $2.6 \times 10^{4}$ to $<10 \mathrm{cfu} / \mathrm{g}$ with an average $2.68 \times 10^{3}$ and ranged from $6 \times 10^{3}$ to $<10 \mathrm{cfu} / \mathrm{g}$ with an average $6.8 \times 10^{2}$ for the powdered and reconstituted forms of the salep samples, respectively (Table 2).

On other hand, only one positive sample of the hot chocolate has the rmophilic bacteria in a percentage of $4 \%$ for both powdered and reconstituted forms; 40 $\mathrm{cfu} / \mathrm{g}$ was the average count of both powdered and reconstituted forms of the hot chocolate samples with a maximum count of $1 \times 10^{3} \mathrm{cfu} / \mathrm{g}$ for both. The results of coffee milk powder samples for total the rmophillic count could be detected only in the powdered form in one sample $(4 \%)$ with a count ranged from $1 \times 10^{3}$ to $<10 \mathrm{cfu} / \mathrm{g}$ with an average count of $40 \mathrm{cfu} / \mathrm{g}$.

Table 3 revealed that the average count of total yeasts and molds of the powdered form of the salep samples was $1.72 \times 10^{3} \mathrm{cfu} / \mathrm{g}$ with counts ranged from $1 \times 10^{4}$ to $<10 \mathrm{cfu} / \mathrm{g}$, while in the reconstituted form, the average count was $9.6 \times 10^{2}$ and the counts ranged from $7 \times 10^{3}$ to $<10 \mathrm{cfu} / \mathrm{g} .12$ and $32 \%$ were the percentages of the positive examined samples of the powdered and reconstituted forms of the hot chocolate, respectively, with the maximum counts $2 \times 10^{3}$ and $1 \times 10^{4} \mathrm{cfu} / \mathrm{g}$ and the average counts $1.6 \times 10^{2}$ and $9.2 \times 10^{2} \mathrm{cfu} / \mathrm{g}$. The maximum, minimum and average counts of the powdered and reconstituted forms of coffee milk powder samples were $1.1 \times 10^{4} \& 2.1 \times 10^{4}$ and $<10 \&<10$ and $1.01 \times 10^{3}$ $\& 2.6 \times 10^{3} \mathrm{cfu} / \mathrm{g}$, respectively.

The results documented in Table 4 showed that the average counts of total Bacillus count of the powdered form of the examined samples of salep, hot chocolate and coffee milk powder were $4 \times 10^{2}$, $3.2 \times 10^{2}$ and $40 \mathrm{cfu} / \mathrm{g}$, with maximum and minimum counts ranged from $5 \times 10^{3}$ to $<10,2 \times 10^{3}$ to $<10$ and $1 \times 10^{3}$ to $<10 \mathrm{cfu} / \mathrm{g}$, respectively. The percentages of the positive samples of the reconstituted form of the same products respectively were 28,40 and $8 \%$ where the maximum counts of the salep, hot chocolate and coffee milk powder samples recorded $1.8 \times 10^{4}, 1.8 \times 10^{4}$ and $4 \times 10^{3} \mathrm{cfu} / \mathrm{g}$, respectively.

The manufacture of salep is based on traditional method without any regard to the quality of raw material used and/ or the hygienic quality of the products. Under such conditions, many microorganisms can find access to the milk products (Soomro et al., 2002) leading to a low shelf life of the base products. Most of these products are sold in the market without proper packaging and unduly exposing them to atmospheric contamination and has become an important public health issue and a great concern to everybody. In developing countries, fruit juices, drinks, meals and snacks sold by street-food vendors are widely consumed by millions of people (Tambekar et al., 2011).

From Table 5, B. megaterium, B. subtilis, $B$. circulans, $B$. licheniformis and $B$. maceranswere detected in percentages $8,8,4,8$ and $4 \%$ in the examined samples of salep in the powdered form while in the reconstituted form, $B$. subtilis, $B$. licheniformis, $B$. sphaericus, $B$. coagglans, $B$. stearothermophilus and $B$. polymyxawere isolated and identified in percentages of 4, 4, 4, 8, 4 and 4\%, respectively. Other Bacillus spp. could be found in the examined samples of hot chocolate in the powdered form as $B$. megaterium, $B$. circulans, $B$. licheniformis, B. macerans and B. stearothermophilus in percentages of $8,4,4$, 4and $4 \%$, respectively. After preparation of the hot chocolate samples according to manufacturing procedures, B. megaterium, B. subtilis, B. circulans B. coagglans and B. stearothermophilus were detected in 2,3,1, 1 and 1 of the examined samples, respectively. B. licheniformis, B. sphaericus and $B$. coagglans were isolated from the powdered form of coffee milk powder samples in percentages of 4, 4 and 4\%, respectively. B. megaterium, B. subtilis, $B$. licheniformis, $B . \quad$ sphaericus, $B$. stearothermophilus and $B$. polymyxa were present in the examined samples of coffee milk powder in the reconstituted form.

B. stearothermophilus are extremely heat resistant, up to 20 times more resistant than Clostridiumbotulinum spores (Iciek et al., 2008). B. stearothermophilus spores typically survive canningand sterilization procedures of food products and may cause spoilage problems especially where foods must be stored atelevated temperatures for a long time. Growth of $B$. stearothermophilus spores results in flat sour spoilage because acid is produced but with little or no gasgenerated (Brackett, 2001).

Regarding, the incidence of $B$. cereus isolated from the powdered and reconstituted forms of salep 
samples were 24 and $36 \%$, respectively. Also, Table 5 showed that the incidence of $B$. cereus in both the powdered and reconstituted forms of hot chocolate samples was $16 \%$.B. cereus was isolated from 8 and $12 \%$ of the powdered and reconstituted forms of coffee milk powder examined samples, respectively. A microbiological risk assessment defined the risk of $B$. cereus as gastroenteritis associated with consumption of vended hot chocolate. High level of $B$. cereus isolation does not indicate an immediate risk to public health; however, it may indicate a suboptimal hygienic conditions and further improvement on the hygienic measures is required. The production of powdered hot chocolate drinks can involve the use of a variety of powdered products as; whey powder, powdered milk, powdered milk protein and cocoa powder which found to have the potentially contaminated $B$. cereus and also has been identified in hot drinks vended from automatic vending machines. Chung- Wang et al. (1993) couldidentify $B$. cereus in vended hot chocolate and cocoa, while Nelms et al. (1997) could isolate B. cereus within a vended hot chocolate drink, in and around the mixing bowl of the vending machine.

Figures $1 \mathrm{a} \& \mathrm{~b}$ referred to the enterotoxigenic $B$. cereus that could be detected by multiplex PCR. Two types of virulent genes for characterization of $B$. cereus were used; hblC (695bp) and cytK (565 bp). All the $28 \mathrm{~B}$. cereusisolates were tested for the presence of both enterotoxin genes. The figures cleared that out of 28 strains of B. cereus, 12 were harbored hblC gene. However, the cytotoxic (cytK) gene was found in 5 strains which lack hblC gene. Elsewhere, 11 strains carried both types of genes were noticed. So this study revealed that all the $B$. cereus isolates from the examined dried dairy products were enter otoxigenic.

Food manufacturer may need to observe good personal and hygienic practices on handling and storage of ingredients for preparation of salep; prevent packaging contamination and avoid prolonged storage under high temperatures.

Chung-Wang et al. (1993) examined 4 varieties of hot drinks obtained from automatic vending machines in Taiwan. A number of specific organisms were also isolated from the drinks and drinks powders by biochemical means. Coffee had a microbial load of $1.5 \log \mathrm{cfu} / \mathrm{ml}$. Apowder of chocolate mix was free from $B$. cereus. The absence of $B$. cereus from cocoa powders may call into question the sensitivity of the test procedures used, as it is a common contaminant and wasfound within the vended drink. A variety of other Bacilli were identified within the powder including B. subtilis and licheniformis. B. cereus that found contaminating the drink was confirmed positive for emetic toxin production. Levels of $B$. cereus above $10^{5} / \mathrm{g}$ are thought to be required to produce sufficient toxin to cause illness (Granum, 1997).
Contamination of liquid milk with $B$. cereus and its spores can also lead to the presence of the organism within any powdered food product containing powdered milk. The contamination of powdered milk and other products derived from powdered milk with $B$. cereus has been widely reported (Wijnands et al., 2006).B. cereus has also been found in other dried food products such as potato (Turner et al., 2006), pepper (Chooet al., 2007) and importantly, cocoa and hot chocolate powder (Gabis et al., 1970, TeGiffel et al., 1996; Ardhana and Fleet, 2003).

The examined salep samples were found to have hygienic problems in the present study. Hygienic conditions of the ingredients used may be a contributing factor to the microbiological quality of this product.

Although $B$. cereus has been recognized as a cause of food poisoning for more than 30 years, it is still difficult to control, especially in the dairy industry. Morphological, biochernical, serological and toxigenic characteristics are commonly used to identify and classify B. cereus (Tallen and Kotewicz, 2012).

Further research should focus on the identification and characterization of the microorganisms found within the dried dairy drinks to provide information on the source of contamination and the population dynamic within the products.

\section{REFERENCES}

A.P.H.A. (1992): Standard Methods for the Examination of Dairy Products. $13^{\text {th }}$ Ed., American Public Health Association. Academic Press: 2062-2065.

American Chemical Society (2003): Hot cocoa Tops red wine and tea in antioxidants; may be Healthier choice. Science Daily, 6 November 2003.

Andersson, A.; Ronner, U. and Granum, P. (1995): What problems does the food industry have with the spore-forming pathogens Bacillus cereus and Clostridium perfringens. Int. J. Food Microbiol., 28: 145-155.

Ardhana, M. and Fleet, G. (2003): The microbial ecology of cocoa bean fermentations in Indonesia, International Journal of Food Microbiology, 86, pp: $87-99$.

Brackett, R.E. (2001): Fruits, vegetables, and grains.In: Doyle, M., Beuchat, L.R., Montville, T.J. (Eds.), Food Microbiology, Fundamentals and Frontiers, second ed. ASM Press, Washington, D.C, pp. 127-138.

Burgess, S.A.; Lindsay, D. and Flint, S.H. (2010): Thermophilic bacilli and their importance in dairy processing. Inter. J. Food Microbiol., 144: 215-225. 
Choo, E.; Jang, S.; Kim, K.; Lee, K-G.; Heu, S. and Ryu, S. (2007): Prevalence and genetic diversity of Bacillus cereus in dried red pepper in Korea, Journal of Food Protection, 70, 917 -922 .

Chung-Wang, Y-J.; Kuo, L-P., Lin, A-Y.; Hong, J. and Tsai, $Y-Y$. (1993): Microbial sanitary properties of cup soft drinks and hot beverages from automatic vending machines in Taiwan, Journal of Food and Drug Analysis, 2, pp 199 -205 .

Davidson, A. (1987): Oxford Companion to food. Oxford University. Press. ISBN 0-19-2115790.p.683.

Ehling-Schulz, M.; Guinebretière, M.; Monthan, A.; Berge, O.; Fricker, $M$. and Svensson, $B$. (2006): Toxin gene profiling of enterotoxic and emetic Bacillus cereus. FEMS Microbiology Letters 260(2): 232-240.

FDA (Food and Drug Administration) (1998): U.S. Department of Health and Human Services. Center for Drug Evaluation and Research (CDER). October 1998. Internet at http://www.fda.gov/cder/guidance/index.htm

Frank, J.F. and Yousef, A.E. (2004): Thermophilic bacteria. In: Wehr, M.H., Frank, J.F. (Eds.), Standard Methods for the Examination of Dairy Products. American Public Health Association, Washington, DC.230-231.

Gabis, D.;Langlois, B. and Rudnick, A. (1970): Microbiological examination of cocoa powder, Applied Microbiology, 20, 644 - 645.

Giffel, M.C.; Beumer, R.;Leijendekkers, S. and Rombouts, F.M. (1996): Incidence of Bacillus cereus and Bacillus subtilis in foods in the Netherlands. Food Microbiol., 13, 1996, 5358.

Gilliland, S.E.; Michener, H.D. and Kraft, A.A. (1976):Psychrotrophic microorganisms. In: Compendium of Methods for the Microbiological Examination of Foods. M.L. Speek (ed.) $2^{\text {nd }}$ Ed., American Public Health Association.

Granum, P. (1997): Bacillus cereus. In Food Microbiology Fundamentals and Frontiers (Doyle, M., Beuchat, L. and Montville, T., Eds.), ASM Press, Washington DC, pp $327-$ 336.

Griffiths, M.W. (1990): Toxin production by psychrotrophicBacillus spp. present in mius. J. Food Prot., 53: 790- 792.

Harrigan, W.F. and MacCance, M.E. (1976): Laboratory Methods in Food and Dairy Microbiology. Academic Press Inc., London.

Iciek, J.; Blaszczyk, I. and Papiewska, A. (2008): The effect of organic acid type on thermal inactivation of Geo Bacillus stearothermophilus spores. J. Food Eng. 87: 16-20.

Koneman, E.; Allen, S.; Janda, W.; Schrenchen, P. and Winn, W. (1992): Color atlas and Text book of Diagnostic Microbiol. $4^{\text {th }} \mathrm{Ed}$
Published by L.B Lippincott Company, Philadelphia, USA.

Meer, R.R.; Baker, J.; Bodyfelt, F.W. and Griffiths, N.W. (1991): Psychrotrophic Bacillus spp. in fluid milk products: A review. J. Food Prot., 54: 969-979.

Nelms, P.; Larson, O. and Barnes-Josiah, D. (1997): Time to B. Cereus about hot chocolate, Public Health Reports, 112, $240-244$.

Ngamwongsatit, P.; Busari, W.; Pianariyanon, P.; Pulsrikarn, C.; Ohba, M.; Assavanig, A. and Panbangred, W. (2008): Broad distribution of entertoxin genes (hblCDA, nheABC, cytK, and entFM) among Bacillus thuringiensis and Bacillus cereus as shown by novel primers. Inter. J. Food Microbiol., 121: 352-356.

Schoeni, J.L. and Wang, A.C. (2005):Bacillus cereus food poisoning and its toxins. J. Food Prot., 68: 636-648.

Sciscenti, M.J. (2015): "Why We Drink Hot Chocolate in the Winter". The Guardian. Retrieved February 17, 2015.

Shah, D.; Shringi, S.; Besser, T. and Call, D. (2009): Molecular detection of foodborne pathogens, Boca Raton: CRCPress, In Liu, D. (Ed). Taylor and Francis group, Florida, USA, Pp. 369-389.

Shittu, T.A. and Lawal, M.O. (2007): Factors affecting instant properties of powdered cocoa beverages. Food Chemistry 100: 91-98. doi:10.1016/j.foodchem.2005.09.01.

Soomro, A.H.; Arain, M.A.; Khaskheli, M. and Bhutto, B. (2002): Isolation of Escherichia coli from raw milk and milk products in relation to public health sold under market condition at Tandojam. Pak. J. Nutr., 1:3, 151-152.

Sorhaug T. and Stepaniak L. (1997):Psychrotrophs and their enzymes in milk and dairy products: Qualityaspects. Trends Food Sci. Technol., 8, 35-41.

Tallen, S.A. and Kotewicz, K.M. (2012): Efficient Isolation and Identification of Bacillus cereus Group. Journal of AOAC International 94:446-451.

Tambekar, D.H.; Kulkarni, R.V.; Shirsat, S.D. and Bhadange, D.G. (2011): Bacteriological quality of street vended food panipuri: a case study of Amravati city (ms) India. Biosc. Disc. 2:350-354.

TeGiffel, M.; Beumer, R.; Leijendekkers, S. and Rombouts, F. (1996): Incidence ofBacillus cereus and Bacillus subtilis in foods in the Netherlands, Food Microbiology, 13, 53 - 58.

TeGiffel, M.; Beumer R.; Christianson A. and Griffiths M. (2000): Bacillus cereus in milk and milk products.Advances in detection, typing and epidemiology. BulletinIDF, 357: 47-54.

Turner, N.; Whyte, R.; Hudson, J. and Kaltovei, S. (2006): Presence and growth of Bacillus cereus in dehydrated potato flakes and hotheld, ready-to-eat potato products purchased in 
New Zealand, Journal of Food Protection, 69, 1173 - 1177.

Varadaraj, M.C. (1993): Methods for detection and enumeration of food born bacterial pathogenes. A critical evaluation. J. Food Sci. Technol., 1993, 30, 1-13.

Wijnands, L.; Dufrenne, J.; Rombouts, F.; Veld, P. and van Leusden, F. (2006): Prevalence of potentially pathogenic Bacillus cereus in food commodities in the Netherlands, Journal of Food Protection, 69, 2587 - 2594.
Wouters, J.T.M.; Ayad, E.H.E.; Hugenholtz, J. and Smit, G. (2002): Microbes from raw milk for fermented dairy products. Int. Dairy J., 12, 91109.

Zhang, Z.; Feng, L.; Xu, H.; Liu, C.; Shah, N.P. and Wei, H. (2016): Detection of viable enterotoxin-producing Bacillus cereus and analysis of toxigenicity from ready-to-eat foods and infant formula milk powder by multiplex PCR. J. Dairy Sci.; 99(2): 1047-55.

\section{التقييم الميكروبيولوجي لبعض المشروبات اللبنية المجفة والمباعة في مدينة أسيوط مروة محد نبيل الجندي ، زينب محد عبل الحميل}

E-mail: Zenb@dr.com; moazahmednofel@yahoo.com

Assiut University web-site: www.aun.edu.eg

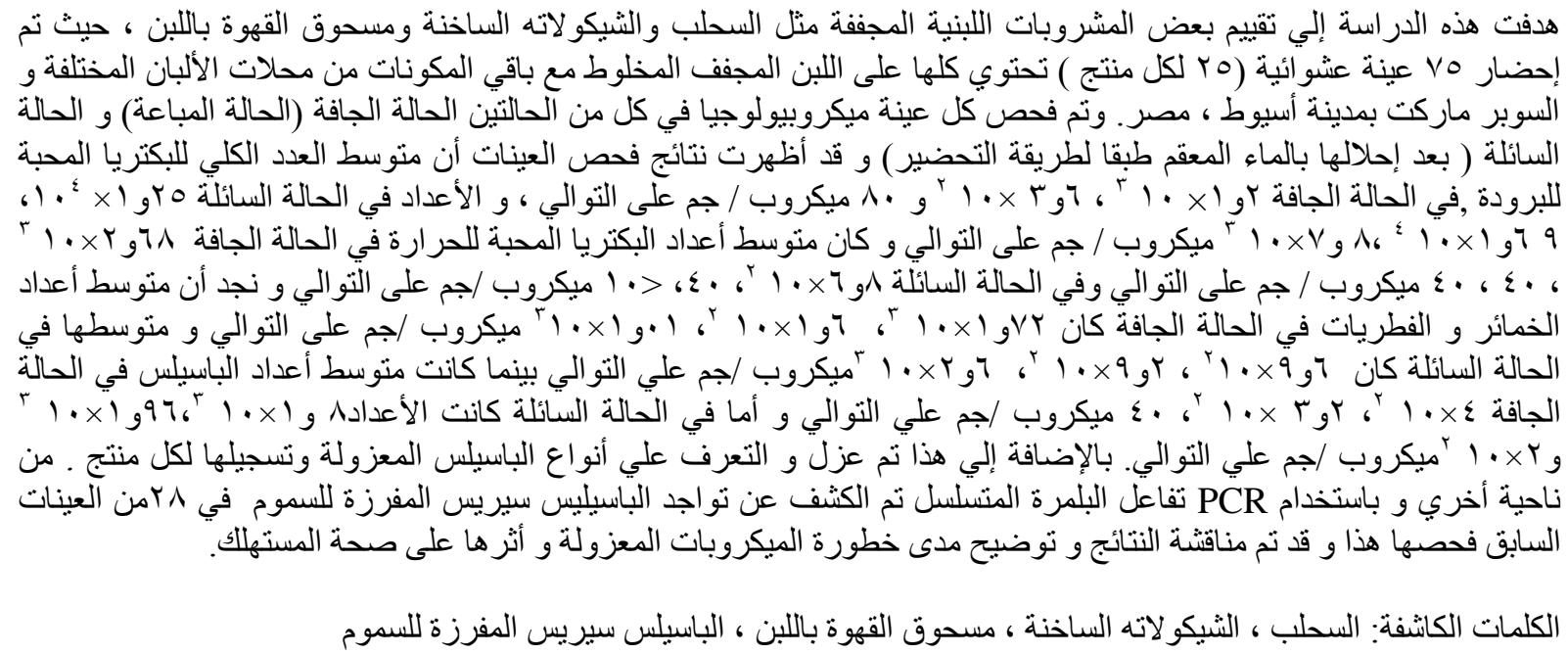

